\title{
UPAYA MENINGKATKAN HASIL BELAJAR IPS DENGAN MENGGUNAKAN MODEL PEMBELAJARAN KOOPERATIF TIPE STUDENT TEAMS ACHIEVEMENT DIVISION (STAD) DENGAN BERBANTUAN MEDIA GAMBAR KELAS IV SD MUHAMMADIYAH PAHANDUT PALANGKA RAYA TAHUN PELAJARAN 2017/2018
}

\author{
OLEH :NUREETA YIRAN*Suniati, M.Pd
}

\begin{abstract}
ABSTRAK
Penelitian ini bertujuan untuk: (1) Untuk mendeskripsikan aktivitas belajar peserta didik kelas IV SD Muhammadiyah Pahandut Palangka Raya pada mata pelajaran IPS dengan menggunakan Model Kooperatif Tipe Student Teams Achievement Division (STAD) dengan berbantuan Media Gambar, (2) Untuk meningkatkan hasil belajar IPS menggunakan model Kooperatif Tipe Student Teams Achievement Division (STAD) dan berbantuan Media Gambar pada peserta didik kelas IV di SD Muhammadiyah Pahandut Palangkaraya.

Jenis penelitian yang digunakan oleh peneliti adalah menggunakan Penelitian Tindakan Kelas (PTK) yang berusaha memecahkan atau menjawab permasalahan yang dihadapi pada situasi sekarang. Subjek dalam penelitian ini adalah terdiri dari 25 orang peserta didik, 10 orang laki-laki dan 15 orang perampuan. Untuk teknik pengumpulan data yang digunakan adalah observasi dan tes. Sedangkan dalam penelitian ini mengunakan analisis data secara kualitatif dan kuantitatif.
\end{abstract}

Hasil penelitian ini menunjukkan bahwa : (1) Aktivitas belajar IPS peserta didik menjadi baik selama mengikuti proses pembelajaran dengan mengunakan model Kooperatif Tipe Student Teams Achievement Division (STAD) dan berbantuan Media gambar. (2) Adanya peningkatan hasil belajar IPS peserta didik selama mengikuti pembelajaran dengan mengunakan model Kooperatif Tipe Student Teams Achievement Division (STAD) dan Media gambar.

Kata Kunci : Hasil Belajar, IPS, Student Teams Achievement Division dan Media Gambar

\section{PENDAHULUAN}

Pendidikan merupakan suatu proses dalam mengembangkan potensi sumber daya manusia guna mewujudkan insan pembangunan yang berbudaya dan bermartabat. Untuk mewujudkan hal tersebut tentunya diperlukan upayaupaya serta usaha yang maksimal. Melalui pendidikan dapat mengembangkan segala potensi yang dimiliki oleh peserta didik melalui proses pembelajaran sehingga pendidikan harus dilaksanakan dengan sebaik-baiknya untuk memperoleh hasil yang maksimal. pendidikan hendaknya dikelola, baik secara kualitas maupun kuatitas.

Pendidikan umumnya dibagi menjadi tahap seperti prasekolah, sekolah dasar, sekolah menengah dan kemudian perguruantinggi, universitas atau magang. Pendidikan merupakan hal yang terpenting dalam kehidupan kita, ini berarti bahwa setiap manusia berhak 
mendapat dan berharap untuk selalu berkembang dalam pendidikan. Pendidikan secara umum mempunyai arti suatu proses kehidupan dalam mengembangkan diri setiap individu untuk dapat hidupdan melangsungkan kehidupan, usaha-usaha dalam membelajarkan peserta didik merupakan bagian yang sangat penting dalam mencapai keberhasilan tujuan pembelajaran yang sudah di rencanakan. Begitu pula dengan pendidikan sekolah seperti di SD karena saat di sekolah dasar diberikan tiga aspek dasar, yaitu pengetahuan sikap, dan keterampilan, tiga aspek tersebut juga dijumpai disalah satu materi pembelajran di SD yaitu Ilmu Pengetahuan Sosial, kegiatan pembekalan di lakukan selama enam tahun berturut-turut saat inilah peserta didik dididik dan di tuntu untuk sikap sebaik-baiknya. Arti sekolah dasar sebagai basis pendidikan wajib sangatlah bisa di pahami oleh semua orang jadi mereka bisa mengikuti pola pendidikkannya. pastinya dalam faktor ini kegiatan pendidikan dan pembelajarannya mengedepankan landasan bagi kegiatan selanjudnya. kegiatan belajar mengajar merupakan sesuatu kompleks karena banyak hal yang perlu mendapatkan perhatian dari guru. Mengajar bukan hanya sekedar menyampaikan suatu materi terhadap peserta didik atau sekedar bertatap muka dengan peserta didik dan memberi suatu materi pelajaran yang akan di ajarkan sesuai jam pelajaran yang hingga selasai, tetapi bagaimana cara menyampaikan meteri pembelajaran tersebut agar lebih menarik perhatian peserta didik agar mereka aktif dan bersemangat dalam mengikuti kegiatan belajar.
Secara sederhana perlu kita ketahui pengertian belajar adalah proses perubahan tingkah laku seorang. Definisi sederhana ini menunjukkan bahwa proses belajar mengajar bukan hanya menhafal fakta-fakta tetapi jauh lebih dari itu. Sebagai besar kebanyakan guru hanya memberikan penjelas terhadap peserta didik tetapi tidak mengetahui peserta didik tersebut apakah memahami apa yang dijelaskan, sementara peserta didik hanya diam mendengarkan dengan fasif penjelasan yang di berikan oleh guru.Penggunaan model dan media pembelajaran khususnya model Kooperatif tipe Student Teams Achievement Divisions (STAD) dan media gambar, peserta didik dapat memahami pembelajaran IPS dengan baik.Peserta didik merasa pelajaran IPS membosankan untuk mereka pahami karena proses pembelajaran cenderung monoton terutama tidak menggunakan model maupun media, khususnya model Student Teams Achievement Divisions (STAD) dan media gambar.

Model pembelajaran adalah pedoman berupa program atau petunjuk strategi mengajar yang dirancang untuk mencapai suatu tujuan pembelajaran, dan juga pemilihan media yang tepat. Media pembelajaran adalah sebagai alat bantu peserta didik untuk memahami pembelajaran, Alasan peneliti menggunakan model Kooperatif tipe Student Teams Achievement Divisions (STAD) dan berbantuan media gambar karena untuk mempermudah pembelajaran sehingga peserta didik dapat menerima pembelajaran dengan baik, dan guru pun juga dapat menjelaskan materi dengan baik karena 
adanya bantuan media gambar, pembelajaran dapat berjalan dengan baik.Berdasarkan hasil observasi yang telah dilakukan peneliti di SD muhammadiyah pahandut palangkaraya, Aktivitas belajar peserta didik masih belum aktif, masih ada peserta didik yang asik bermain sendiri saat guru mengajar, peserta didik juga masih belum memahami materi yang telah di ajarkan, peserta didik masih ada yang kurang percaya diri.

Hasil belajar peserta didik kelas IV SD Muhammadiyah Pahandut Palangka Raya pada mata pelajaran IPS masih banyak peserta didik yang nilai tidak memenuhi Kriteria Ketuntasan Minimal (KKM) yang telah ditetap dari sekolah. Adapun kriteria Ketuntasan Minimal (KKM) mata pelajaran IPS di SD Muhammadiyah Pahandut Palangkaraya adalah 75. Peneliti berharap dengan penelitian di sekolah tersebut hasilbelajar peserta didik dapat meningkat.

Mata pelajaran IPS sering dikeluhkan oleh peserta didik sebagai mata pelajaran yang membosankan bagi mereka. kebanyakan peserta didik kalau pada saat pembelajaran IPS merasa terpaksa mengikuti pelajari karena pada dasarnya mereka menganggap pelajaran IPS membosankan. Maka dari itu perlu ada sebuah model dan media pembelajaran yang digunakan dalam proses pelajaran khususnya model Kooperatif tipe Student Teams Achievement Division (STAD) dan media gambar untuk meningkatkan hasil belajar peserta didik. Karena proses pembelajaran kurang efektif akan mempengaruhi hasil belajar peserta didik . Bila kegiatan belajar yang tidak menyenangkan peserta didik akan menjadi malas mengikuti pembelajaran, maka peneliti tertarik untuk melakukan penelitian dengan judul “ Upaya Meningkatkan Hasil Belajar IPS Dengan Menggunakan Model Pembelajaran Kooperatif Tipe Student Teams Achievement Division (STAD) dan berbantuan Media Gambar di Kelas IV SD Muhammadiyah Pahandut Palangkaraya Tahun Pelajaran 2017/2018"Menurut Rusman (dalam Risky, 2011:215) langkah-langkah pembelajaran kooperatif tipe STAD sebagai berikut :

a. Penyampaian Tujuan dan Motivasi

Menyampaikan tujuan pelajaran yang ingin dicapai pada pembelajaran tersebut dan memotivasi siswa untuk belajar.

b. Pembagian Kelompok

Siswa dibagi ke dalam beberapa kelompok, di mana setiap kelompoknya terdiri dari 4-5 siswa yang memprioritaskan heterogenitas (keragaman) kelas dalam prestasi kademik, genda/jenis kelamin, rasa atau etnik.

c. Presentasi dari Guru

Guru menyampaikan materi pelajaran dengan terlebih dahulu menjelaskan tujuan pelajaran yang ingin dicapai pada pertemuan tersebut serta pentingnya pokok bahasan tersebut dipelajari.

d. Kegiatan belajar dalam tim (kerja tim)

Siswa belajar dalam kelompok yang telah dibentuk.Gurumenyiapkan lembaran kerja sebagai pendoman bagi kerja kelompok, sehingga semua anggota menguasai dan masingmasing memberikan kontribusi. 
e. Kuis(Evaluasi)

Guru mengevaluasi hasil belaajar melalui pemberian kuis tentang materi yang dipelajari dan juga melakukan penilaian terhadap presentasi hasil kerja masing-masing kelompok.

f. Penghargaan prestasi tim

Setelah pelaksanaan kuis, guru memeriksa hasil kerja siswa dan diberikan angka engan rentang 0-100.

Adapun kelebihan dan kelemahan model pembelajaran kooperatif (STAD)

\section{Menurut Rusman (dalam Risky, 2011:217) kelebihan dan kelemahan model kooperatif tipe STAD sebagai berikut :}

1. Kelebihan model pembelajaran kooperatif (STAD)

a. Dapat membrikan kesempatan kepada siswa mengunakan keterampilan bertanya dan membahas suatu masalah

b. Dapat memberikan kesempatan kepada siswa untuk lebih intensif mengadakan penyelidikan mengenai suatu masalah.

c. Dapat mengembangkan bakat kepemimpinan dan mengajarkan keterampilan berdiskusi.

d. Para siswa lebih aktif bergabung dalam pelajaran mereka dan mereka lebih aktif dalam diskusi.

e. Dapat memberikan kesempatan kepada siswa untuk membangkan rasa menhargai, memhormati pribadi temannya, dan menghargai pendapat orang lain.

2. Kelamahan model pembelajaran kooperatif (STAD)

a. Pembelajaran mengunakan model ini membutuhkan waktu yang relative lama, menguras waktu seperti penyajian materidari guru, kerja kelompok dan tes individual/kuis

b. Penggunaan waktu yang lebih lama dapat sedikit diminimalisir dengan menyediakan lembar kegiatan siswa (LKS) sehigga siswa dapat bekerja secara efektif dan efiaien. Sedangkan pembantukan kelompok dan penataan ruang kekas sesuai kelompok yang ada dapat dilakukan sebelum kegiatan pembelajaran di laksanakan.

Media pembelajaran adalah alat yang digunakan sebagai perntara untuk menyampaikan pesan, juga dapat meransung pemikiran, perasaan dan kemauan peserta didik dalam proses belajar mengajar.

Menurut Arsyad (2011:4) menyatakan bahwa: Dengan istilah mediator media menunjukkan fungsi atau perannya, yang mengatur hubungan yang efektif antara 2 pihak utama dalam proses belajar-siswa dan isi pelajaran. Disamping itu, mediator dapat pula mencerminkan pengertian bahwa setiap sistem pembelajaran yang melakukan peran mediasi, mulai dari guru sampai kepada peralatan paling canggih, dapat disebut media. Ringkasnya, media adalah alat yang menyampaikan atau mengantarkan pesan-pesan pembelajaran.

Sedangkan Menurut Jennah (2009:2) menyatakan bahwa :Media pembelajaran adalah segala sesuatu yang dapat digunakan untuk menyalurkan pesan (bahan pembelajaran), sehingga dapat merangsang perhatian, minat, pikiran, perasaan serta minat peserta 
didik guna mencapai tujuan pembelajaran yang diinginkan.Dari pendapat di atas dapat disimpulkan bahwa media pembelajaran adalah suatu alat yang menjadi perantara guna membantu proses penyampaian informasi dalam suatu proses pembelajaran guna menarik perhatian dan minat peserta didik untuk belajar.

Gambar adalah media visual yang berupa goresan-goresan, coretancoretanatau bentuk-bemtuk lain yang dapat menimbulkan tanggapan, persepsi ataupun pemikiran manusia terhadap sesuatu objek atau benda tertentu. Gambar-gambar dimaksud dapat berupa lukisan tangan atau hasil fotografi.

Hal ini dikarenakan siswa lebih menyukai gambar daripada tulisan, apalagi jika gambar dibuat dan disajikan sesuai derngan persyaratan yang baik, sudah tentu akan menambah semangat siswa dalam mengikuti proses pembelajaran. Menurut Jennah (2009:62) "gambar adalah media visual yang berupa goresan-goresan, coretancoretan atau bentuk-bentuk lain yang dapat menimbulkan tanggapan persepi ataupun pemikir manusia terhadap suatu objek atau benda tertentu".Sedangkan Menurut Cecep Kusnandi, dkk (2013:42) menyatakan bahwa : Media gambar adalah media yang berfungsi untuk menyampaikan pesan melalui gambar yang menyangkut indera penglihatan. Pesan yang disampaikan dituangkan melalui simbol-simbol komunikasi visual. Media gambar mempunyai tujuan untuk menarik perhatian, memperjelas materi, mengilustrasikan fakta dan informasi.
Berdasarkan pendapat di atas disimpulkan bahwa media gambar adalah sesuatu yang dapat membawa informasi dan pengetahuan yang dapat menimbulkan tanggapan, persepsi dan pemikiran manusia terhadap gambar tersebut karena bersifat abstrak dan kongkret.

Langkah-langkah Pembelajaran Menggunaan Media Gambar Menurut Widihatmoko (2011:68) langkahlangkah pembelajaran media gambar bisa digambarkan dalam langkahlangkah sebagai berikut :

1. Guru menyampaikan kompetensi yang ingin dicapai.

2. Menyajikan materi sebagai pengantar.

3. Guru menunjukkan/memperlihatkan gambar-gambar yang berkaitan dengan materi.

4. Guru mengelompokkan siswa untuk berdiskusi.

5. Guru menunjuk atau memanggil siswa secara bergantian memasang memilih/menyebut/mengurutkan jenis gambar.

6. Guru menanyakan alasan atau dasar pengertian gambar tersebut.

7. Dari alasan atau urutan gambar tersebut guru mulai menanamkan konsep/materi sesuai dengan kompetensi yang ingin dicapai.

8. Siswa mendapat LKS dan dikerjakan berkelompok.

9. Siswa melakukan tanya jawab antar kelompok dari hasil diskusi mengerjakan LKS.

10. Bersama siswa guru merumuskan kesimpulan atau rangkuman.

11. Guru memberi kesempatan siswa untuk bertanya tentang materi yang belum jelas. 
12. Bersama siswa mengevaluasi hasil materi dan membeikan PR.

Jika guru yakin peserta didik memahami mengunakan media tersebut, maka tahap berikutnya adalah dengan memberikan kesempatan dan dorongan kepada setiap peserta didik mencoba menggunakan media gambar sesuai dengan fantasi dan imajinasi peserta didik.

Kelebihan dan kelemahan media Gambar Sifatnya konkret : Gambar/Foto lebih realistis menunjukkan pokok masalah dibandingkan dengan media verbal semata.

1. Gambar dapat mengatasi batasan ruang dan waktu. Tidak semua benda, objek atau peristiwa dapat dibawah ke kela, dan tidak selalu bisa anak-anak dibawa ke objek/peristiwa tersebut.

2. Media gambar/foto dapat mengatasi keterbatasan pengamatan kita. Sel atau penampang daun yang tak mungkin lihat dengan mata telanjang dapat disajikan dengan jelas dalam bentuk gambar atau foto

3. Foto dapat memperjelas suatu masalah, dalam bidang apa saja dan untuk tingkat usia berapa saja, sehingga dapat mencegah atau membetulkan kesalah pahaman.

4. Foto harganya murah dan gampang didapat serta digunakan, tanpa memerlukan peralatan khusus.

Kelemahan Media Gambar

1) Gambar/foto hanya menekakan persepsi indera mata;
2) Gambar/foto benda yang terlalu kompleks kurang efektif untuk kegiatan pembelajaran;

3) Ukuran sangat terbatas untuk kelompok besar.

\section{METODOLOGI PENELITIAN}

Jenis penelitian yang digunakan dalam penelitian ini adalah penelitian tindakan kelas (PTK) yang bertujuan untuk melakukan perbaikanperbaikan terhadap sistem, isi, dan kompetensi atau situasi pembelajaran dengan menguji cobakan suatu ide ke dalam praktik dan sitiasi nyata dalamproses belajar mengajar di kelas dengan harapan kegiatan tersebut dapat meningkatkanhasil proses belajar mengajar.

Menurut Rapoport (Arifin, 2012:97) "penelitian tindakan kelas digunakan untuk membantu seseorang mengatasi masalah-masalah praktis dalam situasi darurat dan membantu pencapaian tujuan social science secara kolaboratif sesuai dengan norma atau aturan yang disepakati”.

(2012:41) menyatakan bahwa: "penelitian tindakan kelas PTK (Clasroom Action Research) memiliki peranan yang sangat penting dan strategis untuk meningkatkan mutu pembelajaran belajar apabila di inpementasikan dengan baik dan benar".Berdasarkan pendapat di atas maka dapat disimpulkan bahwa Penelitian Tindakan Kelas adalah suatu kegiatan penelitian dengan mencermati sebuah kegiatan belajar yang diberikan tindakan, yang secara sengaja dimulculkan dalam sebuah kelas, yang 
bertujuan memecahkan masalah atau meningkatkan mutu pembelajaran di kelas tersebut.

Subjek dalam penelitian ini adalah seluruh peserta didik kelas IV di SD Muhammadiyah Pahandut Palangkaraya padatahun ajaran 2017/2018 yang berjumlah 25 orang peserta didik,10 laki-laki dan 15 perempuan.

\section{HASIL PENELITIAN DAN PEMBAHASAN}

Pembahasan hasil penelitian di kelas IV di SD Muhammadiyah Pahandut Palangkaraya tahun pelajaran 2017/2018 tentang menerapkan model pembelajaran kooperatif tipe Student Team Achievement Divisions (STAD) dan berbantuan media gambar sebagai berikut:

1. Aktivitas Peserta Didik

a. Siklus I

Berdasarkan analisis data yang dilakukan terhadap aktivitas peserta didik pada siklus I yang memperoleh nilai rata-rata 3,12 dengan kriteria baik. Peserta didik yang kurang aktif selama proses pembelajaran berlangsung, namun pada saat peneliti menerapkan model pembelajaran kooperatif tipe Student Team Achivement Divisions (STAD) dan berbantuan media gambar, Peserta didik menjadi aktif dan saling berkerjasama dalam meningkatkan kosentrasi dan kecepatan berpikir secara kelompok. Karena model pembelajaran kooperatif tipe Student Team Achievement Division (STAD) adalah model yang menekankan adanya aktivitas dan interaksi diantara peserta didik untuk saling memotivasi dan saling membantu dalam menguasai materi. Peserta didik pada awalnya kurang minat dalam mata pelajaran IPS, namun saat peneliti menggunakan model pembelajaran kooperatif tipe Student Team Achievement Division (STAD) dan berbantuan media gambar, peserta didik termotivasi dan tertarik selama proses pembelajaran. Walaupun ada sebagai peserta didik kurang merespon pada saat proses pembelajaran berlangsung.

\section{b. Siklus II}

Data hasil aktivitas peserta didik untuk siklus II lebih meningkat dikarenakan pengunaan model pembelajaran kooperatif tipe Student Team Achievement Divisions (STAD) dan berbantuan media gambar dalam proses pembelajaran peserta didik lebih bersungguh-sungguh untuk mengikuti proses pembelajaran seperti memperhatikan guru pada saat menyampaikan materi pembelajaran, peserta didik sudah baik memberikan tanggapan presentasi temannya dengan bimbingan guru, serta peserta didik sudah baik dalam bertanya tentang apa yang belum dipahami pada saat proses pembelajaran. Hal ini dapat dilihat dari rata-raa siklus II yaitu 3,64 secara keseluruhan. Dengan pembuktian tersebut dapat dikatakan model pembelajaran kooperatif tipe Student Team Achievement Divisions (STAD) dan berbantuan media gambar sangat membantu untuk meningkatkan aktivitas belajar peserta didik, dengan menggunakan model pembelajaran kooperatif tipe Student Team Achievement Divisions (STAD) dan berbantuan media gambar peserta didik menjadi aktif, dapat bekerja sama, berpikir kritis, serta bertukar pendapat dengan kelompoknya. 
Berikut ini adalah grafik aktivitas peserta didik dalam pembelajaran pada saat menggunakan model pembelajaran kooperatif tipe Student Team Achievement Divisions (STAD) dan berbantuan media gambar.

\section{Gambar 3}

\section{Grafik Persentase Aktivitas Belajar}

\section{Peserta Didik}

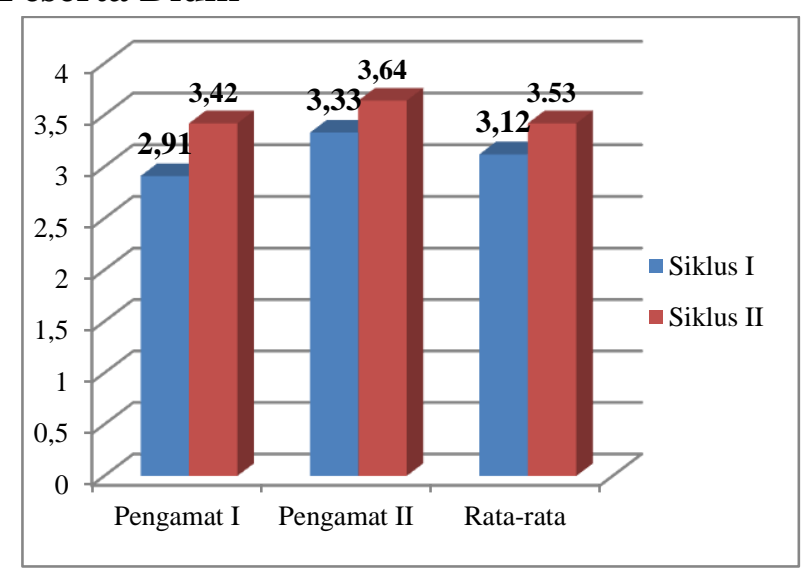

\section{Hasil Belajar Peserta Didik}

Hasil belajar peserta didik mengalami peningkatan hal tersebut dapat dilihat dari data hasil belajar peserta didik yang diperoleh dari data awal dan post test siklus I dan siklus II. Pada data awal hasil belajar peserta didik memperoleh skor rata-rata 55,4 dengan ketuntasan klasikal 12\% sehingga belum memenuhi ketuntasan klasikal 85\%. Kemudian pada siklus I saat diberikan post test hasil belajar peserta didik memperoleh skor rata-rata 70,8 dan ketuntasan klasikal 52\% sehingga belum memenuhi ketuntasan klasikal 85\%. Kemudian pada siklus II pada saat diberikan post test hasil belajar peserta didik memperoleh skor rata-rata 88,6 dan telah mencapai KKM 75, dengan ketuntasan klasikal 100\%. Dari penelitian ini, penerapan model pembelajara kooperatif tipe Student Team Achievement Divisions (STAD) dan berbantuan media gambar dapat meningkatkan hasil belajar IPSdengan materi masalah sosial mampu meningkatkan hasil belajar peserta didik.

Meningkatnya hasil belajar peserta didik melalui model pembelajaran kooperatif tipe Student Team Achievement Divisions (STAD) dan berbantuan media gambardapat meningkatkan konsentari dan kecepatan berpikir, peserta didik menjadi aktif, dapat bekerja sama, berpikir kritis, serta bertukar pendapat dengan temannya.

Berikut ini adalah peningkatan hasil belajar peseta didik pada data awal, pelaksanaan tindakan siklus I dan pelaksanaan tindakan siklus II.

\section{KESIMPULAN}

Berdasarkan hasil penelitian tindakan yang telah dibahas maka dapat disimpulkan sebagai berikut:

1. Aktivitas belajar peserta didik kelas IV SD Muhammadiyah Pahandut Palangkaraya tahun pelajaran 2017/2018 dalam pmbelajaran IPS termasuk dalam kategori baik setelah diterapkan model STAD dan berbantuan media gambar.

2. Dapat meningkatan hasil belajar IPS melalui model STAD dan media gambar pada peserta didik kelas IV SD Muhammadiyah Pahandut Palangkaraya tahun pelajaran 2017/2018.

\section{DAFTAR PUSTAKA}

Arsyad, A. (2011). Media Pembelajaran. Jakarta: PT Raja Grafindo Persada.

Jennah, Rodihatul. (2009). Media Pembelajaran. Banjarmasin Antasari : Press. 
Tunas Jurnal Pendidikan Guru Sekolah Dasar, Juni 2019, Volume 4 Nomor 2, (16-25) ISSN : 2477-6076

Cecep Kusnandi, Bambang Sojtipto.

(2013). Media Pembelajaran

Manual dan Digital. Bogor:

Ghalia Indonesia

Arifin, Zaina.(2012) Penelitian Pendidikan

Metode Dan Paradigm Baru. Bandung : PT

Remaja

Rosdakarya 
Tunas Jurnal Pendidikan Guru Sekolah Dasar, Juni 2019, Volume 4 Nomor 2, (16-25) ISSN : 2477-6076 